\title{
Destructive and Potentially Destructive Insects of Snakeweed in Western Texas and Eastern New Mexico and a Dioristic Model of their Biotic Interactions
}

\author{
JAMES K. WANGBERG
}

\begin{abstract}
The relationships of the principal destructive and potentially destructive insects associated with Xanthocephalum microcephalum (DC) Shinners (threadleaf snakeweed) and Xanthocephalum sarothrae (Pursh) Shinners (broom snakeweed) have been identified and depicted with a dioristic model. Every region of the host plant is utilized by insects in one or more of the following feeding categories: defoliators, fluid feeders, borers, and gall-formers. Roots, stems, leaves, flowers, and fruit each have their own complement of insect associates. A system analysis reveals a complex picture of insect-host plant interactions as well as potential insectinsect interactions. The roles that these insects play in the natural biological control of threadleaf and broom snakeweed are poorly understood but the general information portrayed in the model of their interactions will help future workers to determine the most productive avenues of research.
\end{abstract}

Snakeweed species, Xanthocephalum microcephalum (DC) Shinners (threadleaf snakeweed) and Xanthocephalum sarothrae (Pursh) Shinners (broom snakeweed), although native to much of western North America (Correll and Johnston 1970) are considered noxious weeds in many areas. After the drought in the United States during the 1950 's, large areas of rangeland in the western half of Texas became heavily infested by these two species (Ragsdale 1969). Pressures of overgrazing have also promoted their spread (Stoddart et al. 1975) but the cyclic nature of their populations prevent their use as reliable indicators of overgrazing (Jameson 1970, Vallentine 1971). In heavily populated areas broom snakeweed is highly competitive with perennial grasses on short grass prairie rangelands (Ueckert 1979). An additional negative attribute is the toxic effect the snakeweeds have on livestock. Both are toxic to cattle, sheep, and goats, as well as other animal species (Sperry et al. 1964).

Control attempts with herbicides against broom snakeweed have been erratic and mostly unsuccessful (Sosebee et al. 1979). The use of fire has also been explored but with mixed results (Dwyer 1967). A third control strategy, biological control using insects, has been proposed as having some potential (Foster et al. 1981). Insects have been successfully manipulated for the control of other noxious plant species in North America (Goeden and Louda 1976, Zwolfer and Harris 1971, Wilson 1964, Huffaker 1959). The traditional or "classical" approach in these biological

\footnotetext{
The author is associate professor, Department of Entomology, Texas Tech University, Lubbock, Texas 79409 .

This article is Texas Tech University College of Agricultural Sciences Manuscript No. T-10-130.

Manuscript received June 20, 1980.

Insect species were determined by the following persons: H.R. Burke, Department of Entomology, Texas A\&M University; D.C. Ferguson, L. Knutson, D.R. Miller, Insect Identification and Beneficial Insect Introduction Institute, U.S. Dep. Agr., Agr. Res. Serv., Beltsville, Md.; J.A. Powell. Department of Entomology. University of California, Berkeley; D.B. Richman, Department of Entomology, New Mexico State University, Las Cruces; E. L. Sleeper, Department of Biological Sciences, California State University, Long Beach.

lllustrated by Amy McPhail.
}

control efforts has been to introduce natural exotic enemies to control alien weed species. Special considerations are necessary when introducing foreign species to control nativc weeds (DeLoach 1978). Alternative approaches to the control of native weeds are augmentation and conservation of naturally occurring enemies and the manipulation of the environment to enhance the effects of the controlling agent(s) (DeLoach 1978). An initial effort to identify the naturally occurring insects on threadleaf and broom snakeweed revealed $300+$ species associated with them (Foster et al. 1981). The next phase in our understanding of the potential of any one or more of these species to suppress the plant is to more clearly define the roles of the most numerous and conspicuous insects associated with the shrub. The purpose of this paper is to (1) identify the destructive and potentially destructive insects of snakeweed, (2) clarify their relationships to the host plant and to the other insect associates, and (3) formulate a model to depict the insect-insect and insect-host plant interactions.

\section{Study Area and Procedures}

This study was conducted from the spring 1978 to the spring 1980 in areas of western Texas and eastern New Mexico with heavy infestations of threadleaf snakeweed and broom snakeweed. A total of 195 collections were made within a 13 count area. In Texas, collections were made in the western counties extending from Dumas, Moore County, in the north to areas of Pecos County in the south. In New Mexico, collections were confined to areas of Lea County.

Sampling of insects occurred at ca. 2-4 week intervals throughout the summer period and monthly or twice monthly in the fall, late winter, and early spring when the host plant was not dormant. The entire plant was visually examined in the field for the presence of destructive insects or insects suspected of being harmful. The foliage was inspected for defoliators or signs of defoliators such as tied leaves, plant fluid feeders, and gall-formers and their galls. Representatives of conspicuous or numerous insect species were collected and preserved in $75 \%$ ethanol. Mature galls, leaf tier pupae, and other insects nearing adult emergence were collected and returned live to an insectary for rearing and ultimate species determination. Following examination of the above-ground part of the plant, it was uprooted and inspected for insects on and within the roots. Their collection, preservation, and rearing were handled as for the other insects. The numbers of insects collected from each plant were recorded and their relative frequencies determined. For the purpose of this paper the following categories are defined for the occurrence of each species: $\geq 20 \%$ plants infested $=$ frequent; $11-19 \%$ plants infested $=$ occasional; $1-10 \%$ plants infested $=$ inf requent.

At each collection site data were gathered on biotic and abiotic factors deemed pertinent to the long-range goals of the study. These included temperature, weather conditions, and site charac- 
teristics such as topography, soil texture, exposure, etc. Principal biotic features noted were plant species present, condition of host plant, stage of host plant development, \% canopy cover, and biological observations of insects associated with the plant.

\section{Host Plants}

To aid in understanding the insect relationships of both species, the host plant can be divided into four major regions (Fig. 1). Each region is supportive of a variety of insect species that fall within different feeding categories (Table I). Although there may be some overlap among some species in certain regions, an analysis of the principal insect species occupying each region helps clarify the important relationships between insect and host plant as well as the potential insect-insect interactions.

\section{Destructive and Potentially Destructive Insects}

\section{Defoliators}

These species are often the most conspicuous insects on snakeweed, particularly those that tie stems and leaves together with silk. Within infested areas $24 \%(95 / 395)$ of the snakeweed had one or more leaf tiers present. Four species of Lepiodoptera in the families Pyralidae and Tortricidae are common leaf tiers in western Texas. Synnoma lynosyrana Walsh. (Tortricidae) is the only one that has received any attention in the literature (Powell 1976, Foster et al. 1981). The others include two probable new species of Tortricidae and Phyralidae (and perhaps a new genus) and Sarata incanella (Hulst) (Pyralidae). The larvae of one or more of these species can be found feeding on leaves from the onset of plant growth in the early spring to the flowering stage in late summer and early fall. The combined effect of defoliation and tied folige results in an unsightly appearance of the host plant. The impact that these

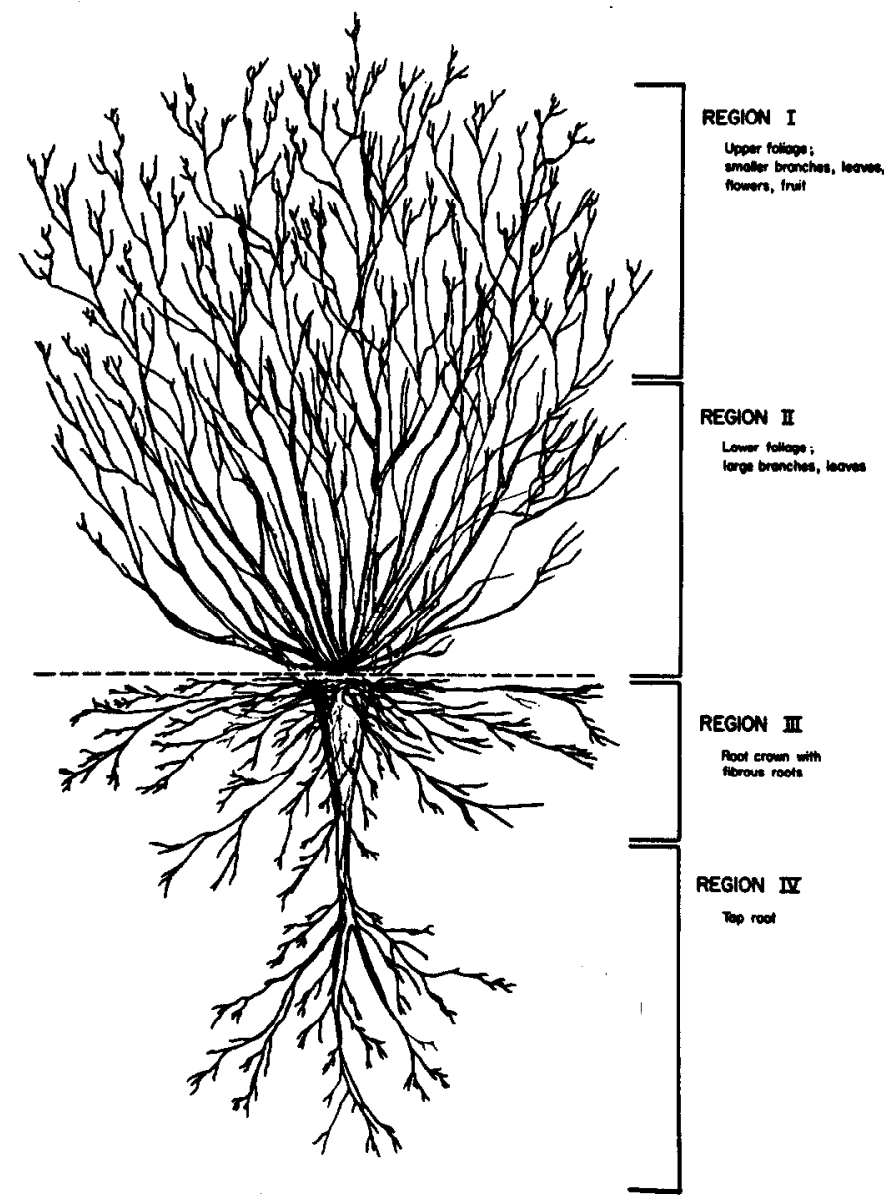

Fig. 1. Snakeweed with regions defined according to insect utilization. Plant hetght may range from $15 \mathrm{~cm}$ to $10 \mathrm{dm}$. insects, either alone or in combination, have on the host plant has not been established.

Other conspicuous defoliators on snakeweed include grasshoppers (Acrididae) and weevils (Curculionidae). Both groups may be abundant at times but the occurrence of grasshoppers is typically cyclic and the weevils are phytophagous on the host plant foliage only briefly as adults in late summer.

\section{Plant Fluid Feeders}

A wide range of plant fluid feeding insects attack all regions of the host plant. Above-ground parts of the plants are infested by two conspicuous families of scale insects. The giant scale, Steatococcus townsendi Cockerell (Margarodidae), and the red scale, Tachardiella glomerella Cockerell (Kermidae), are found feeding on branches and stems. Although they occur infrequently (1-9\%), the presence of at least the red scale may be significant. At each location where it was encountered, $100 \%$ of the plants infested were dead or partially killed. The effect which this insect may have on snakeweed is in need of further investigation.

Of additional interest, due to their frequent occurrence $(60 / 190)$ and usual large numbers, are the mealybugs Eriococcus cryptus (Eriococcidae) and Pseudococcus sp. (Pseudococcidae). Both species feed on the roots of snakeweed. It is common to collect plants with roots literally covered with these insects. In spots of severe infestations, there are no apparent harmful effects on the host plant. The long-term impact of large populations of mealybugs feeding upon roots is unknown.

\section{Borers}

Within the stems and/or roots are three families of beetles (Buprestidae, Cerambycidae, Curculionidae) and one moth family (Olethreutidae) that cause noticeable structural damage to the plant. Each of thesc has also been recorded for Arizona (Hetz and Werner 1979). Foster et al. (1981) make special note of two of the beetle families among others for their potential impact on the plant. The mode of attack by each of the root borers is not alike. Myrmex sp., a new and yet undescribed weevil species, bores within the lower branches as an early instar but is most destructive during later instars as it tunnels extensively throughout the root crown and upper tap root. The damage is increased by the frequent occurrence of more than one larva per plant. As many as eight larvae have been found in a single plant, although three to five are more common. In contrast to Myrmex, there are borers that tunnel the length of the tap root. Crossidius pulchellus Le Conte (Cerambycidae) and Eucosma ridingsana (Olethreutidae) are solitary borers and may hollow out a considerable portion of the root by the time they reach maturity. The occurrence of Crossidius on broomweed has been mentioned by several investigators (Hetz and Werner 1979, Penrose 1967, Lensley and Chemsak 1961) and it is currently the subject of research in New Mexico (pers. comm., Richman). Eucosma ridingsana, on the other hand, has only been referred to once in regard to its association with snakeweed (Hetz and Werner 1979). To the best of my knowledge, it has not been previously recorded on snakeweed in Texas. Another root borer, Agrilus sp. (Buprestidae), is found as a solitary feeder throughout the tap root but the extent of its damage is lessened due to its smaller size and confinement to outer root tissues.

\section{Gall-formers}

Only one family of insects (Dipt: Cecidomyiidae) has been observed forming galls on snakeweed; however, their occurrence is common and widespread. Galls were noted on 26 percent of the plants $(29 / 110)$. Galled stems or leaves were found on at least some plants at every collection site. Felt (1940) lists 2 species of gallformers on snakeweed; however, I have found other galls that do not fit the descriptions of galls formed by these known gallformers. The damage by gall-formers to the host plant may be confined to local injury but the effect of heavy infestations on the host plants' vigor is unknown.

\section{Others}

Occasionally the larvae of some undetermined species of Elateri- 
Table 1. Spatial distribution, feeding categories, and principal species of destructive insects associated with snakeweed in western Texas and eastern New Mexico. 1977-79.:

\begin{tabular}{|c|c|c|c|c|}
\hline \multirow[b]{2}{*}{ Principal insect species } & \multicolumn{4}{|c|}{ Plant Regions ${ }^{1}$} \\
\hline & I & II & 111 & IV \\
\hline \multicolumn{5}{|l|}{ Orthoptera } \\
\hline \multirow{2}{*}{\multicolumn{5}{|c|}{ Homoptera }} \\
\hline & & & & \\
\hline \multicolumn{5}{|l|}{ Margarodidae } \\
\hline Pseudococcidae & Fluid feeder & & & \\
\hline $\begin{array}{l}\text { Pseudococcus sp. } \\
\text { Eriococcidae }\end{array}$ & & & Fluid feeder & Fluid feeder \\
\hline $\begin{array}{l}\text { Eriococcidae } \\
\text { Eriococcus cryptus }\end{array}$ & & & Fluid feeder & Fluid feeder \\
\hline $\begin{array}{l}\text { Kermidat } \\
\text { Tachardiella glomerella }\end{array}$ & Fluid feeder & Fluid feeder & & \\
\hline $\begin{array}{l}\text { Coleoptera } \\
\text { Buprestidae }\end{array}$ & & & & \\
\hline $\begin{array}{l}\text { Agrilus sp. } \\
\text { Cerambycidae }\end{array}$ & & & Borer & Borer \\
\hline Crossidius pulchellus & & & Borer & Borer \\
\hline $\begin{array}{l}\text { Curculionidae } \\
\text { Myrmex sp. } \\
\text { misc. species }\end{array}$ & & Borer & Borer & \\
\hline Lepidoptera & General detoliator & & & \\
\hline $\begin{array}{l}\text { Pyralidae } \\
\text { Sarata incanella } \\
\text { undetermined species }\end{array}$ & $\begin{array}{l}\text { Leaf tier } \\
\text { Leaf tier }\end{array}$ & $\begin{array}{l}\text { Leaf tier } \\
\text { Leaf tier }\end{array}$ & & \\
\hline Tortricidae & & & & \\
\hline $\begin{array}{l}\text { Synnoma lynosyrana } \\
\text { Probable new genus }\end{array}$ & Leaf tier & Leaf tier & & \\
\hline $\begin{array}{l}\text { nr. Synnoma } \\
\text { Olethreutidae }\end{array}$ & Leaf tier & Leaf tier & & \\
\hline Eucosma ridingsana & & & Borer & Borer \\
\hline Diptera & & & & \\
\hline $\begin{array}{l}\text { Cecidomyiidae } \\
\text { undetermined species }\end{array}$ & Gall-former & Gall-former & & \\
\hline
\end{tabular}

'Regions defined and illustrated in Figure 1.

dae and Tenebrionidae are found in soil in close proximity to the fibrous roots. They have not been observed feeding on the plants nor has damage been found that would indicate such feeding; however, members of both families are known to commonly inhabit soil and attack plant roots.

\section{Systems Analysis of Insect-Host Plant Interactions}

Due to the large numbers of insect species associated with Xanthocephalum spp. (Foster et al. 1981) and the complexity in understanding their relationship to the host plant, it is helpful to take a systems approach in analyzing the interactions among insects and host plants. The associations of principal insect species to various regions of the host plant is an initial step in this systems approach.

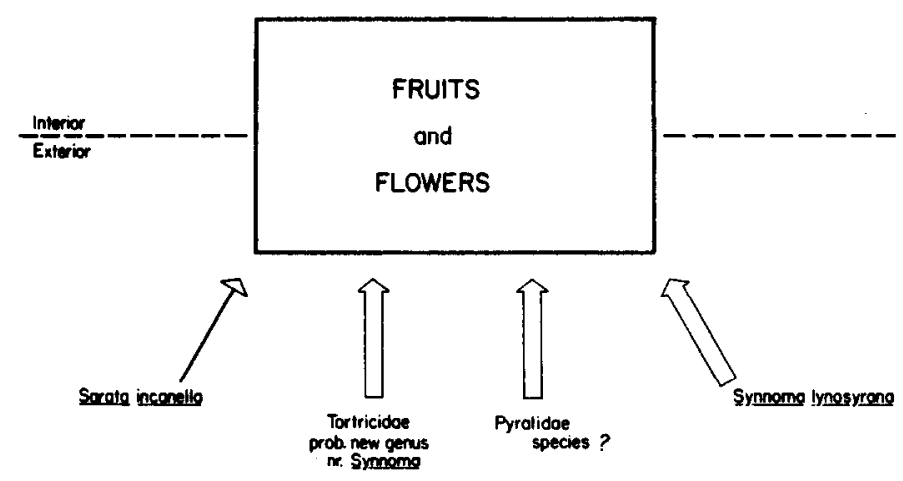

Fig. 2. Frequencies of principal insect species utilizing snakeweed fruits and flowers (arge arrows $=$ frequent; small arrow $=$ infrequent).
Relationships are more clearly defined within each region by modeling the interactions among insects and specific plant structures. Thus, it becomes clear that flowers, fruit, stems, leaves, and roots each have their own complement of insect associates (Fig. 2-5). The complexity of each sub=model is not only a function of the number of species attacking the particular plant structure but also a function of their physical position, either on the exterior or in the interior of the plant and their relative frequencies.

An added level in the systems' complexity is achieved when the sub-models are combined into an overall dioristic model (South-

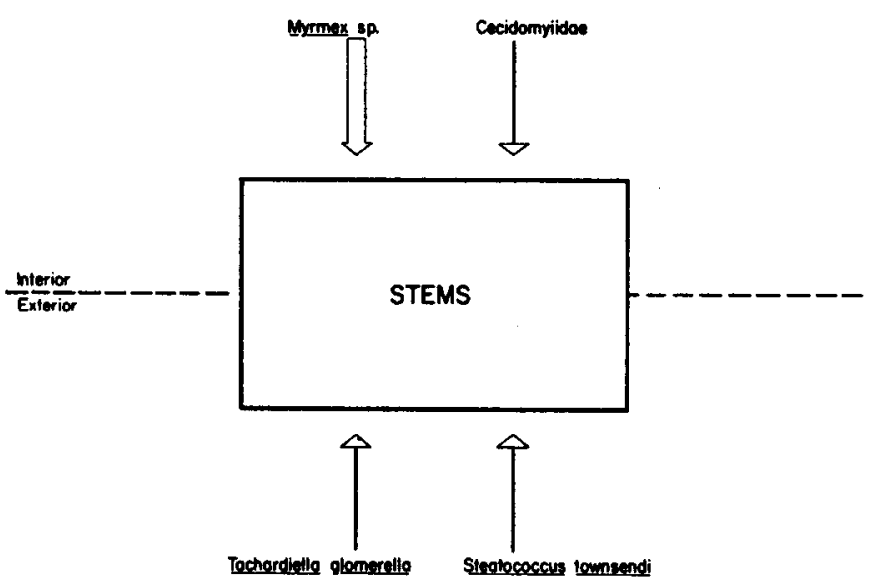

Fig. 3. Frequencies of principal insect species utilizing snakeweed stems (large arrow = frequent; small arrows = infrequent). 


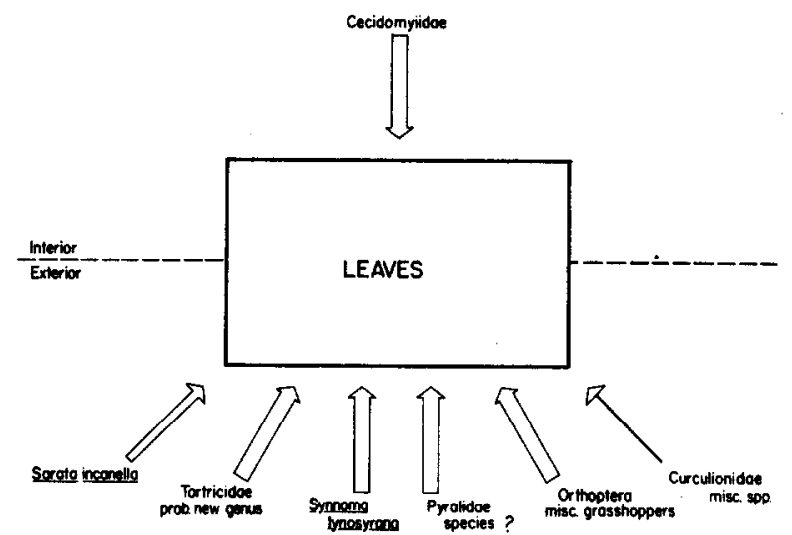

Fig. 4. Frequencies of principal insect species utilizing snakeweed leaves large arrows $=$ frequent; medium arrows $=$ occasional; small arrows $=$ infrequent).

wood 1978) that represents the total insect-host plant interactions (Fig. 6). It becomes clear from the model that a variety of insect groups (as defined earlier by feeding categories) rely on the same part of the host plant. For instance, stems are utilized by weevil borers, cecidomyiid gall-formers and scale insects sucking on plant fluids. Similar overlap among these and other insect groups is apparent at the roots, leaves, flowers, and fruit. Consequently, certain potential insect-insect interactions become apparent as well. In the absence of some mode(s) of resource partitioning among insects utilizing the same plant parts, there would naturally result varying degrees of interspecific competition. It is likely that many such mechanisms exist and hence we are presented with a very complex picture of a plant species being attacked by several insects over a continuous period of time. The re is currently a need to examine the specific interactions between those insect species with the greatest potential to inflict damage upon the host plant.

The model presented herein clarifies the roles of some of the principal insects that attack threadleaf and broom snakeweed. To date, biological information on each species is fragmentary and it is premature to assess the degree of natural biological control exerted by them. Before such an assessment can be made, it is critical that we understand the broader picture of the total insect-host plant interaction. As pointed out by Stark and Smith (1971), "such a model will at first be crude, but it will reveal gross features of the pest system under study. It will aid in determining what are the most valuable data which should be collected, which phenomena should be investigated more thoroughly and even dictate or suggest what experiments should be conducted to bring realism to the model."

\section{Literature Cited}

Correll, D.S., and M.C. Johnston. 1970. Manual of the vascular plants of Texas. Texas Res. Foundation, Renner, Texas. 1881 p.

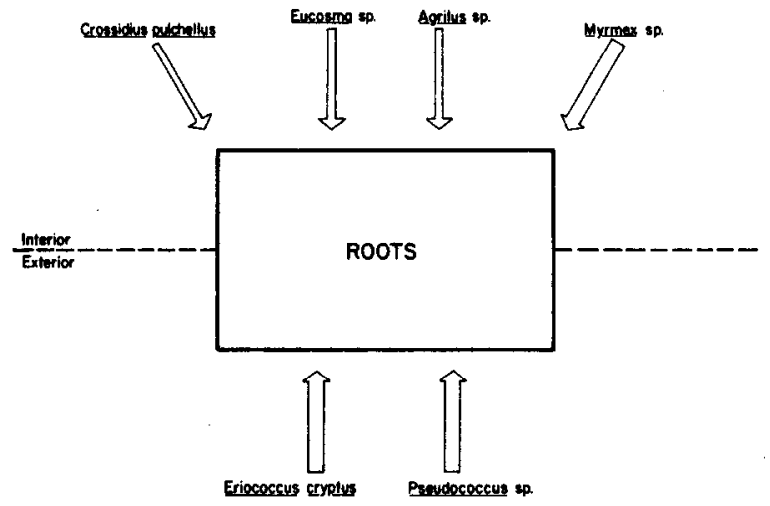

Fig. 5. Frequencies of principal insect species utilizing snakeweed roots (large arrows $=$ frequent; medium arrows $=$ occasional).

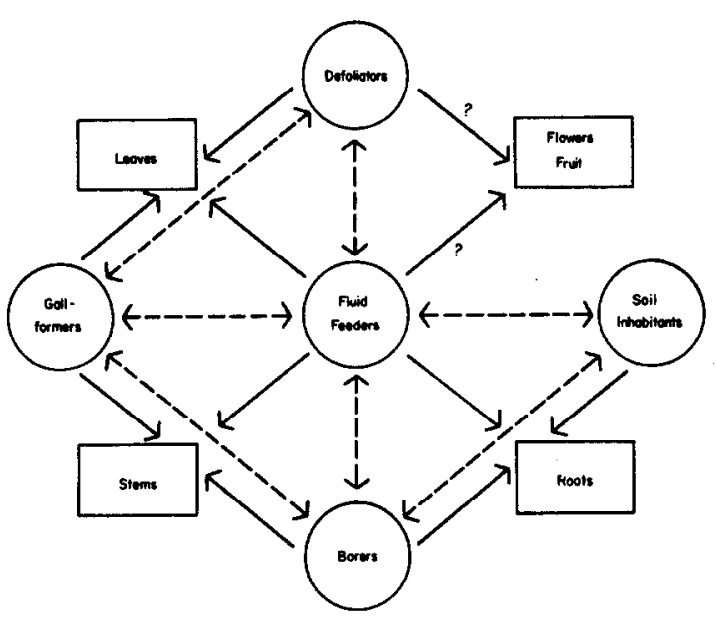

Fig. 6. Model of the interactions among the destructive insects associated with snakeweed (solid lines = insect-plant interactions; dash lines = potential insect-insect interactions; ? = relationship not observed but inferred).

DeLoach, C.J. 1978. Considerations in introducing foreign biotic agents to control native weeds on rangelands. Proc. IV International Symposium on Biological Control of Weeds. 39-50.

Dwyer, D.D. 1967. Fertilization and burning of blue grama grass. J. Animal Sci. 26:934.

Felt, E.P. 1940. Plant galls and gall-makers. Comstock Pub. Co., Ithaca, N.Y. 364 p.

Foster, D.E., D.N. Ueckert, and C.J. DeLoach. 1981. Insects associated with broom snakeweed and threadleaf snakeweed in west Texas and eastern New Mexico. J. Range Manage. 34:446-454.

Goeden, R.D., and S.M. Louda. 1976. Biotic interference with insects imported for weed control. Annu. Rev. Entomol. 21:325-342.

Hetz, M.W., and F.G. Werner. 1979. Insects associated with roots of some rangeland Compositae in southern Arizona. Southwestern Entomol. $4: 285-288$.

Huffaker, C.B. 1959. Biological control of weeds with insects. Annu. Rev. Entomol. 4:251-276.

Jameson, D.A. 1970. Value of broom snakeweed as a range condition indicator. J. Range Manage. 23:302-304.

Linsley, E.G., and J.A. Chemsak. 1961. A distributional and taxonomic study of the genus Crossidius (Coleoptera, Cerambycidae). Misc. Pub. Entomol. Soc. America 3:25-64.

Penrose, R.L. 1967. Bionomics of the species of Idaho Crossidius with taxonomy of the immature stages (Coleoptera: Cerambycidae). MS Thesis, Univ Idaho. $68 \mathrm{p}$.

Powell, J.A. 1976. Host plant preference, mating and egg development in Synnoma lynosyrana. Pan-Pac. Entomol. 52:1-12.

Ragsdale, B.J. 1969. Ecological and phenological characteristics of perennial broomweed. PhD Diss., Texas A\&M University. $138 \mathrm{p}$.

Sosebee, R.E., W.E. Boyd, and C.S. Brumley. 1979. Broom snakeweed control with tebuthiuron. J. Range Manage. 32:179-182.

Southwood, T.R.E. 1978. Ecological methods. 2nd ed. Chapman and Hall, London. $524 \mathrm{p}$.

Sperry, U.E., J.W. Dollahite, G.O. Hoffman, and B.J. Camp. 1964. Texas plants poisonous to livestock. Texas Agr. Exp. Sta. Bull. B-1028. 59 p.

Stark, R.W., and R.F. Smith. 1971. Systems analysis and pest management. p. 331-345. in Biological Control, C.B. Huffaker, ed. Plenum Press, N.Y. 511 p.

Stoddart, L.A., A.D. Smith, and T.W. Box. 1975. Range Management. 3rd ed. McGraw-Hill Book Co., Inc., New York. 532 p.

Ueckert, D.N. 1979. Broom snakeweed: effect on short grass forage production and soil water depletion. J. Range Manage. 32:216-220.

Vallentine, J.F. 1971. Range development and improvements. Brigham Young Univ. Press, Provo, Utah. 516 p.

Wilson, F. 1964. The biological control of weeds. Annu. Rev. Entomol. 9:225-244.

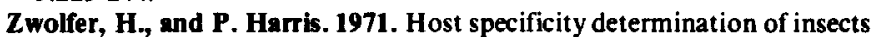
for biological control of weeds. Annu. Rev. Entomol. 16:159-178. 